\title{
AORA Checklist: First Confirm Then Perform
}

Archana Areti ${ }^{1}$, Ritesh Roy ${ }^{2}$, Kapil Gupta ${ }^{3}$, Vrushali Ponde ${ }^{4}$, Mohammad Azam Danish ${ }^{5}$, Neha Singh $^{6}$, Amjad Maniar ${ }^{7}$, Rammurthy Kulkarni ${ }^{1}$ Department of Anaesthesia, Mahatma Gandhi Medical College Research Institute Puducherry, India.

${ }^{2}$ Associate Clinical Director and HOD, Care Hospitals, Bhubaneshwar, Odisha, India.

${ }^{3}$ Department of Anaesthesia, Vardhaman Mahavir Medical College \& Safdarjung Hospital, New Delhi, India.

${ }^{4}$ Director Child Anaesthesia Services, Mumbai, Maharashtra, India. ${ }^{5}$ Department of Anaesthesia, B. M. Jain Hospital, Bengaluru, Karnataka, India.

${ }^{6}$ Department of Anaesthesia, AIIMS, Bhubhaneshwar, Odisha, India.

${ }^{7}$ Department of Anaesthesia, Axon Anaesthesia Associates, Bengaluru, Karnataka, India.

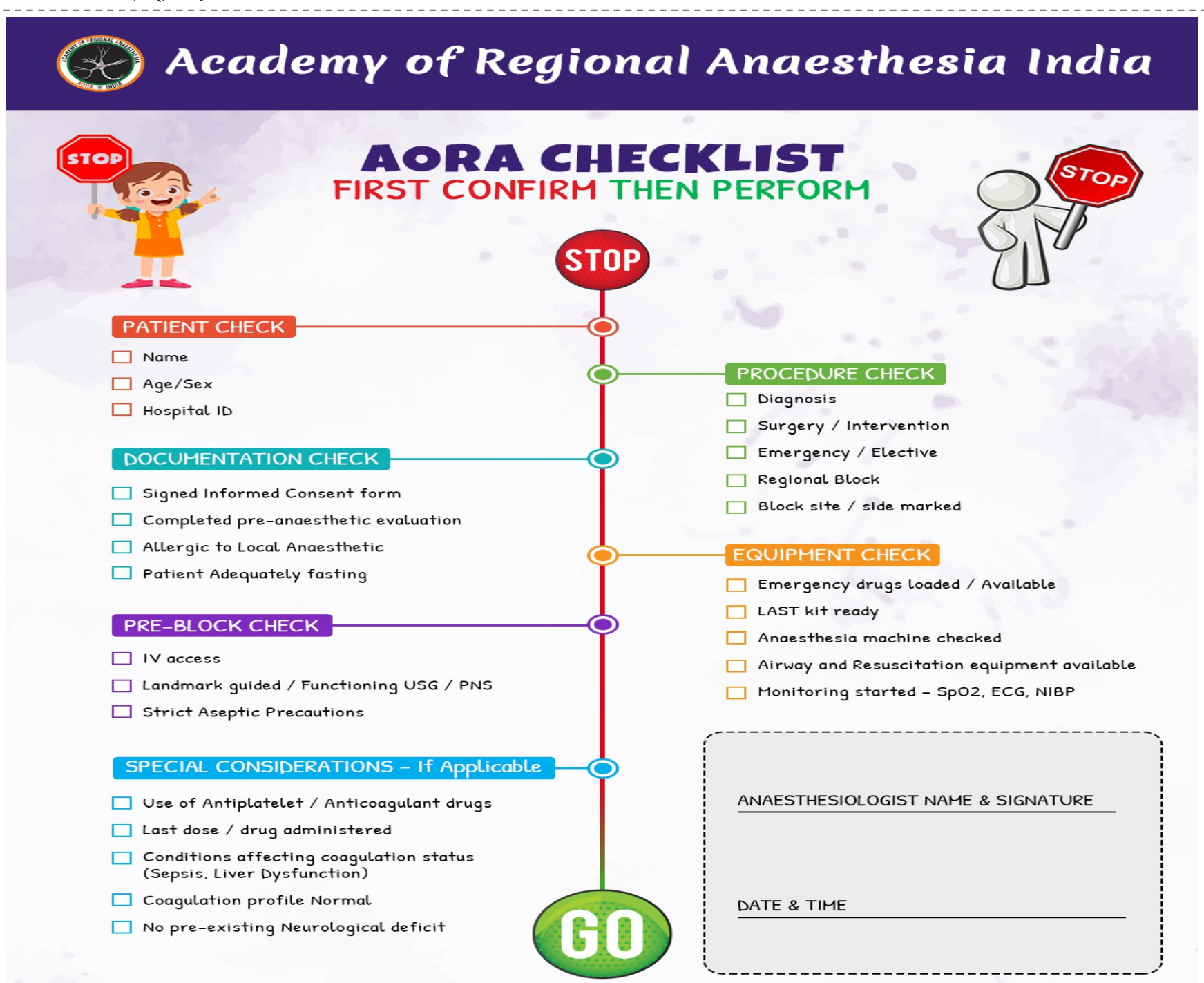

Take due precautions to minimize Corona Virus spread. Stay safe.

An initiative by

The Protocols and Guidelines Team of AORA India

\section{www.aoraindia.com}

Address of Correspondence: Dr. Vrushali Ponde, Director Child Anaesthesia Services, Mumbai, Maharashtra, India. E-mail:vrushaliponde@gmail.com DOI: 10.13107/ijra.2021.v02i01.017 | (c) 2021 International Journal of Regional Anaesthesia | Available on www.ijrajournal.com | This is an Open Access article distributed under the terms of the Creative Commons Attribution Non-Commercial License (http://creativecommons.org/licenses/by-nc/3.0) which permits unrestricted non-commercial use, distribution, and reproduction in any medium, provided the original work is properly cited.

How to cite this article: Areti A, Roy R, Gupta K, Ponde V, Danish MA, Singh N, Maniar A, Kulkarni R | AORA Checklist: First Confirm Then Perform | International Journal of Regional Anaesthesia | January-June 2021; 2(1): 04. 